\title{
Quantitative and qualitative assessment of microbial aerosols in different indoor environments of a dental school clinic
}

\author{
Seyed Hamed Mirhoseini $(\mathbb{D} \cdot$ Ali Koolivand • Mojtaba Bayani · Hamid Sarlak • \\ Rahmatollah Moradzadeh • Farhad Ghamari • Adel Sheykhan
}

Received: 9 March 2020/ Accepted: 21 November 2020/Published online: 13 January 2021

(C) The Author(s), under exclusive licence to Springer Nature B.V. part of Springer Nature 2021

\begin{abstract}
In the indoor environment of dental clinics, dental staff and patients are exposed to various types of infectious agents transported by aerosols and particles, generated during dental procedures, promoting an increased risk of cross-infection. The aim of this study was to determine the levels and diversity of microbial aerosol in relation to particle load in five different departments of a dental school clinic. The air samples were collected by an active single-stage Andersen sampler during the treatment procedure. The mean concentrations of airborne bacteria were in the
\end{abstract}

\section{S. H. Mirhoseini $(\bowtie) \cdot$ A. Koolivand}

Department of Environmental Health Engineering, School of Health, Arak University of Medical Sciences, Golestan Ave, Ghods St, Arak, Iran

e-mail: hmirhossaini@gmail.com

M. Bayani · H. Sarlak

Department of Periodontics Dentistry, School of Dentistry, Arak University of Medical Sciences, Arak, Iran

\section{R. Moradzadeh}

Department of Epidemiology, School of Health, Arak University of Medical Sciences, Arak, Iran

F. Ghamari

Department of Occupational Health, School of Health, Arak University of Medical Sciences, Arak, Iran

\section{A. Sheykhan}

Student Research Committee, Arak University of Medical

Sciences, Arak, Iran range of 52-1030 and $8-844 \mathrm{CFU} / \mathrm{m}^{3}$ at the distances of 0.5 and $2 \mathrm{~m}$, respectively. Bacterial aerosols in pediatric, endodontics, and restorative wards and fungal aerosols in all the sampling wards were significantly higher at the distances of $0.5 \mathrm{~m}$. The dominant bacteria and fungi were identified as Micrococcus, Bacillus, Streptococcus, Staphylococcus, Penicillium, Cladosporium, Aspergillus, Rhizopus, and Alternaria. The positive associations were also obtained between bacteria and fungi levels and particulate matter (PM) concentrations.

Keywords Dental school clinic · Bio-aerosol · PM concentration - Airborne bacteria and fungi

\section{Introduction}

Nowadays, the potential for bio-aerosols as a route for disease transmission has been emphasized in dental clinics in terms of infection control. Bio-aerosol generated during dental treatment practices has the potential for the airborne transmission of the disease since the indoor air of the clinic is inhaled by dentists, patients, and dental health care workers. Microbial aerosols emitted from a patient's mouth into the indoor air may stay suspended for long periods (up to six hours) and thereby can be easily breathed into the lungs of a susceptible person (Zemouri et al. 2017). Some bacterial and viral infections are caused by the 
bio-aerosols which were isolated in dental clinics air (Sawhney et al. 2015). The oral cavity constitutes a wide reservoir of infectious organisms with over 350 different types of bacteria (Szymanska 2007). It is known that bio-aerosols are involved in the transmission of pathogens such as SARS (Severe Acute Respiratory Syndrome), Mycobacterium tuberculosis (tuberculosis), Clostridium difficile and Methicillinresistant Staphylococcus aureus (MRSA) in dental offices (Kimmerle et al. 2012; Szymanska 2007; Zemouri et al. 2017). Exposure to airborne fungi can cause various diseases from allergic reactions, irritations, asthma, and pneumonia to toxic effects and infections. The external and internal causes such as environmental conditions, human activity, and ventilation efficiency influence fungal dispersion in dental clinic environments (Kadaifciler and Cotuk 2014). During dental treatment actions, the routine use of instruments such as slow-speed drilling into teeth, bones and tissues generates hazardous bio-aerosols (Sawhney et al. 2015). The bacterial species of Legionella and Pseudomonas were isolated in aerosols generated by instruments using water-air sprays (Zemouri et al. 2017). Also, the use of an ultrasonic scaler increases aerosols contamination in dental offices (Timmerman et al. 2004). Therefore, the bioaerosols composition varies based on the type of dental treatment procedure and oral flora of the patient (Jimson et al. 2015). Previous findings indicated that microbial aerosols have a significant potential for human infection when the particle diameter is 0.5-20 $\mu \mathrm{m}$ (Dawson et al. 2016). The fine particulate matter fraction of aerosols (respirable particles) which includes airborne microorganisms can penetrate deep into the lung alveoli, being attracted into the bloodstream and exhibits systemic effects on human health (Dawson et al. 2016; Sawhney et al. 2015; Schmalz et al. 2018). According to the above, the risk of acquiring infections by bio-aerosols may be a hazard to patients as well as health care workers in the dental offices. The aims of this study were a qualitative and quantitative evaluation of airborne bacteria and fungi in various wards of a dental school clinic and to analyze the influence of treatment type (such as tooth cleaning, restoration, dental fillings, and root canal treatments) on levels of bio-aerosols. The indoor concentrations of particulate matter (PM) including $\mathrm{PM}_{1}, \mathrm{PM}_{2.5}$, and $\mathrm{PM}_{10}$ and their relationship with the airborne bacteria and fungi levels were also assessed.

\subsection{Material and methods}

\subsubsection{Study area and air sampling}

This cross-sectional study was performed in the dental school clinic of Arak University of Medical Sciences, Arak, Iran. Many patients use this special clinic for dental treatment provided by the dentists and students involving in education and treatment. Air sampling was performed in five separate active departments of the clinic, including periodontics, pediatric dentistry, restorative dentistry, prosthesis, and endodontics. During the sampling period in each ward, the mean numbers of occupants was recorded. The details of each sampling section and mean number persons are presented in Table 1. The windows were closed over the whole duration of sampling time. From each ward, two active dental chair units were selected by randomly simple sampling method and the air samples were collected at the distances of 0.5 and $2 \mathrm{~m}$ during the treatment procedure. Each sampling site was visited nine times. Thus:

Number of sampling wards $(W)=5$

Number of sampling chair in each $\operatorname{ward}(C)=2$

Number of sampling distances (0.5 and 2 meters) (D) $=2$

Number of sampling repetitions in each $\operatorname{site}(F)=9$

$$
\begin{aligned}
\text { Total sample size } & =W \times C \times D \times F \\
& =5 \times 2 \times 2 \times 9=180 \text { samples }
\end{aligned}
$$

A total of 180 air samples were taken using the SKC BioStage impactor during the six month period from December 2018 to June 2019. The flow rate of the high flow pump was set at $28.3 \mathrm{l} / \mathrm{min}$ for $5 \mathrm{~min}$. During sampling, temperature and relative humidity were also measured by use of a portable weather station (Kimo) at each sampling site. The average indoor temperature and relative humidity during sampling periods were about $25{ }^{\circ} \mathrm{C} \pm 2.4{ }^{\circ} \mathrm{C}$ and $32 \% \pm 4.6 \%$, respectively. 
Table 1 Characteristics of various sampling departments of the dental clinic

\begin{tabular}{|c|c|c|c|c|c|c|c|}
\hline $\begin{array}{l}\text { Sampling } \\
\text { departments }\end{array}$ & Dental procedure & $\begin{array}{l}\text { Mean } \\
\text { numbers } \\
\text { of } \\
\text { occupants }\end{array}$ & Ventilation system & $\begin{array}{l}\text { Dental } \\
\text { chair } \\
\text { number }\end{array}$ & $\begin{array}{l}\text { Mean } \\
\text { time of } \\
\text { treatment } \\
(\mathrm{min})\end{array}$ & $\begin{array}{l}\text { Area } \\
\left(\mathrm{m}^{2}\right)\end{array}$ & $\begin{array}{l}\text { Sampling } \\
\text { number }\end{array}$ \\
\hline Periodontics & $\begin{array}{l}\text { Scaling, root planning, tooth } \\
\text { extraction, oral and implant } \\
\text { surgeries }\end{array}$ & 22 & $\begin{array}{l}\text { Central operation } \\
\text { HVAC }^{\mathrm{a}}\end{array}$ & 4 & 30 & 50 & 36 \\
\hline Pediatric dentistry & $\begin{array}{l}\text { Restoration, fluoride therapy, } \\
\text { crowns, and pulp therapy }\end{array}$ & 18 & $\begin{array}{l}\text { Central operation } \\
\text { HVAC }\end{array}$ & 5 & 20 & 50 & 36 \\
\hline $\begin{array}{l}\text { Restorative } \\
\text { dentistry }\end{array}$ & Direct restoration and veneers & 16 & $\begin{array}{l}\text { Central operation } \\
\text { HVAC }\end{array}$ & 4 & 20 & 70 & 36 \\
\hline Prosthesis & $\begin{array}{l}\text { Indirect crowns and other } \\
\text { restorations }\end{array}$ & 14 & $\begin{array}{l}\text { Central operation } \\
\text { HVAC }\end{array}$ & 5 & 30 & 90 & 36 \\
\hline Endodontics & $\begin{array}{l}\text { Root canal therapy apexification } \\
\text { and apexogenesis }\end{array}$ & 17 & $\begin{array}{l}\text { Central operation } \\
\text { HVAC }\end{array}$ & 4 & 30 & 55 & 36 \\
\hline
\end{tabular}

${ }^{a}$ HVAC, heating, ventilating, and air conditioning systems

\subsubsection{Isolation and identification of isolates}

Simultaneously in each sampling point, two Andersen impactor was loaded with agar Petri dishes $(90 \mathrm{~mm}$ diameter) containing tryptic soy agar (TSA) with cycloheximide for bacteria and malt extract agar (MEA) with chloramphenicol for fungi. The TSA and MEA agar plates were incubated at $37{ }^{\circ} \mathrm{C}$ for $2-3$ days and $25^{\circ} \mathrm{C}$ (room temperature) for 3-5 days, respectively (Mirhoseini et al. 2020). The colonies were counted and airborne concentrations were calculated as $\mathrm{CFU} / \mathrm{m}^{3}$ (colony forming units/cubic meter of air). The identification of bacteria was performed based on standard procedures, including morphological and microscopy analysis (Gram stain, Biochemical Test).

Identification of fungal colonies was based upon morphological (color, texture, shape, and diameter appearance of colony) and microscopic characteristics (presence of specific reproductive structures, presence/absence of conidia and their size, shape and structure of conidia, septation in mycelium) (Madureira et al. 2015).

\subsubsection{Particle concentration}

Along with the all bioaerosol measurements, PM $\left(\mathrm{PM}_{1}, \mathrm{PM}_{2.5}\right.$ and $\left.\mathrm{PM}_{10}\right)$ concentrations were recorded by a laser photometer (TSI DustTrak 8520) for a halfhour period. The DustTrak was adjusted by ISO
12103-1 (Arizona Test Dust) and was calibrated to a zero filter during the measurement period.

\subsubsection{Statistical analysis}

The min, max, mean, and standard deviations of microbial aerosols and PM concentrations were calculated. The Mann-Whitney U test $(P$-value $<0.05)$ was used to distinguish statistically significant variations in the mean microbial aerosols of each sampling ward at different distances from the dental chair. Also, the Kruskal-Wallis test was used to compare the values of microbial aerosols and PM mass concentrations in different sampling sites. The associations between the analyzed parameter (microbial aerosols, human occupancy, and PM concentrations) were done using Spearman's correlations and recording the correlation coefficient and $\mathrm{P}$ values. The variation in the concentration of $\mathrm{PM}_{10}, \mathrm{PM}_{2.5}$, and $\mathrm{PM}_{1}$ from different sampling sites were presented by data in box and whisker plots.

\section{Results}

The changes of airborne bacteria concentrations at the distances of $0.5 \mathrm{~m}$ and $2 \mathrm{~m}$ from the dental units (during treatment procedure) in different wards are shown in Fig. 1. In total, the level of airborne bacteria 
ranged between 52- 1030 and $8-844 \mathrm{CFU} / \mathrm{m}^{3}$ at the distances of 0.5 and $2 \mathrm{~m}$, respectively. The statistical analysis showed that there was no significant difference (Mann-Whitney test, $p=0.2$ ) in the concentrations of airborne bacteria at the distances of 0.5 and $2 \mathrm{~m}$ for all samples. However, during the treatment procedure in Pediatric, Endodontics and Restorative wards, airborne bacteria level was significantly higher at $0.5 \mathrm{~m}$ than that at $2 \mathrm{~m}(P<0.05)$. The highest level of airborne bacteria was observed in the pediatric ward at $0.5 \mathrm{~m}(489 \mathrm{CFU} / \mathrm{m} 3)$ and in periodontics ward at $2 \mathrm{~m}$ (338 CFU/m3). (Fig. 1). In the present study, airborne fungal loads were $46-198 \mathrm{CFU} / \mathrm{m}^{3}$ at distance $0.5 \mathrm{~m}$ and $27-110 \mathrm{CFU} / \mathrm{m}^{3}$ at $2 \mathrm{~m}$ distance from the dental chair (Fig. 2). The results showed that the concentrations of airborne fungi at a distance of $0.5 \mathrm{~m}$ were significantly higher than those at $2 \mathrm{~m}$ in all sampling sites $(p<0.001)$ (Fig. 2). The periodontic ward at the distances $0.5 \mathrm{~m}$ had the highest concentration (197 CFU/m3) of airborne fungi (Fig. 2). The maximum concentrations of $\mathrm{PM}_{10}, \mathrm{PM}_{2.5}$ and $\mathrm{PM}_{1}$ were found in periodontics ward, while minimum concentrations were found in Endodontics ward (Fig. 3). The Kruskal-Wallis test showed that there were no significant differences in $\mathrm{PM}\left(\mathrm{PM}_{10}, \mathrm{PM}_{2.5}\right.$, and $\mathrm{PM}_{1}$ ) concentrations between different clinic wards $(P=0.406)$. The highest value of $\mathrm{PM}_{10}$ concentration was $119 \mu \mathrm{g} / \mathrm{m}^{3}$, while that for $\mathrm{PM}_{2.5}$ and $\mathrm{PM}_{1}$ were $59 \mu \mathrm{g} / \mathrm{m}^{3}$ and $47 \mu \mathrm{g} / \mathrm{m}^{3}$, respectively (Fig. 3). The correlations between the analyzed parameters are shown in Table $2 . \mathrm{PM}_{10}$ was positively correlated with $\mathrm{PM}_{2.5}(r=0.92, p<0.001)$ and $\mathrm{PM}_{1}$ $(r=0.73, p<0.001)$ (Table 2). Also, there were positive correlation between human occupancy with $\mathrm{PM}_{10} \quad(r=0 . \quad 56, p<0.001), \mathrm{PM}_{2.5} \quad(r=0 . \quad 59$, $p<0.001), \quad$ and $\mathrm{PM}_{1} \quad(r=0 . \quad 44, \quad p<0.05)$

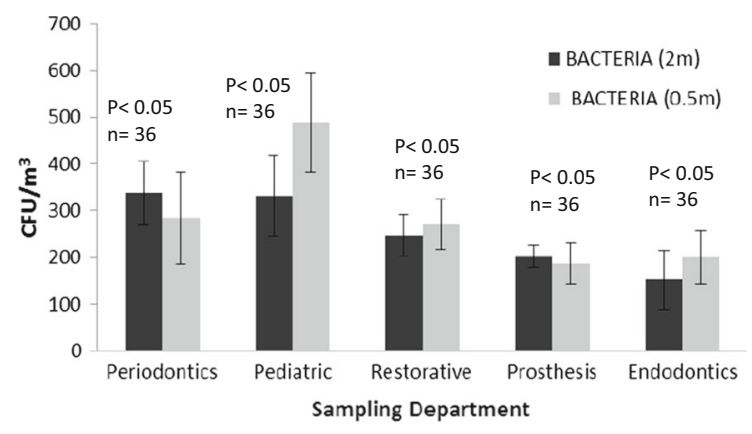

Fig.1 Mean concentrations of airborne bacteria at different dentistry wards at two distances $(0.5$ and $2 \mathrm{~m})$

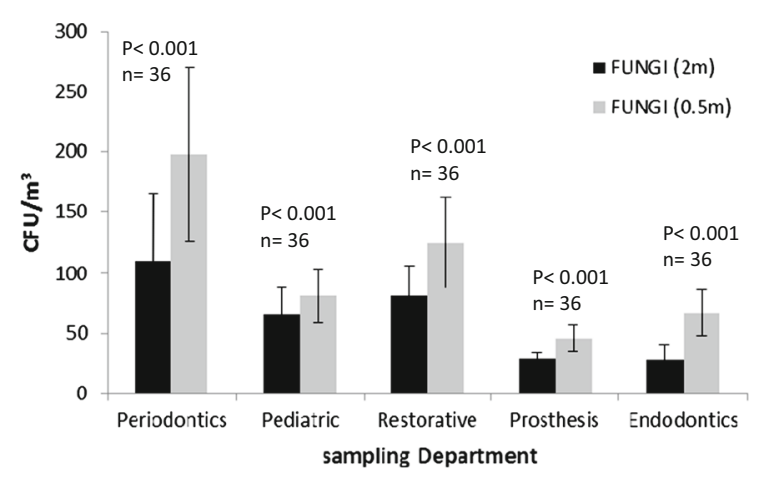

Fig. 2 Mean concentrations of airborne fungi at different dentistry wards at two distances $(0.5$ and $2 \mathrm{~m})$

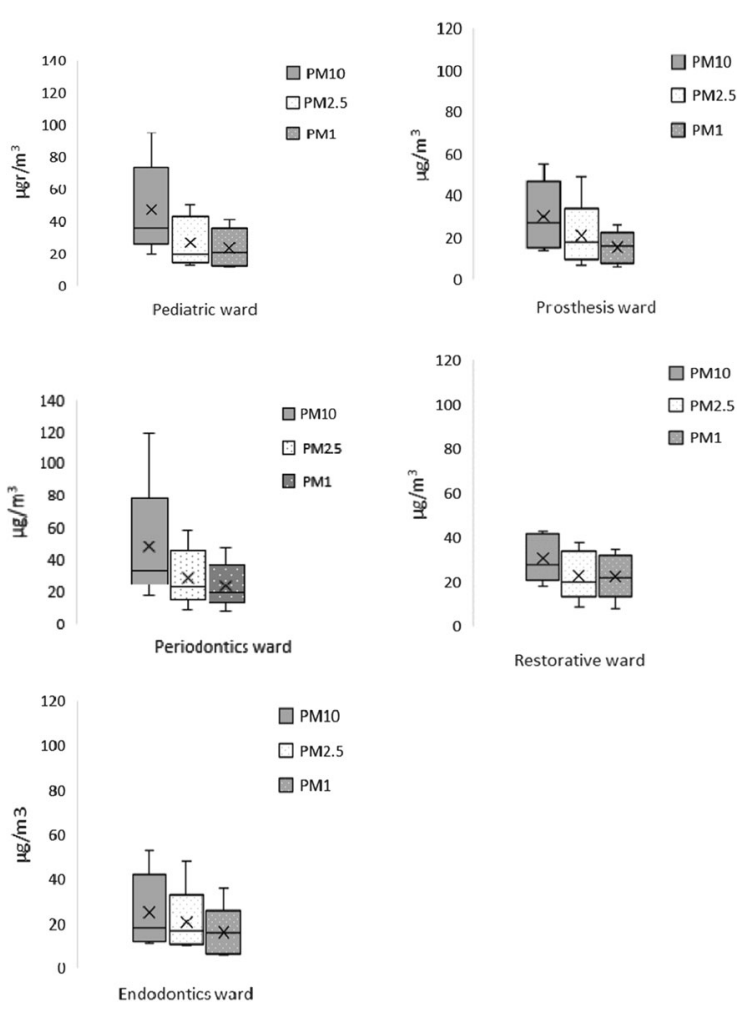

Fig.3 Box-plots of PM mass concentrations $\left(\mathrm{PM}_{10}, \mathrm{PM}_{2.5}\right.$, and $\mathrm{PM}_{1}$ ) measured at five different sampling sites in the school dental clinic [the bottom and top of the box are the minimum and maximum of all the data; the band in the box is median]

concentrations (Table 2). There was a significant relationship between $\mathrm{PM}_{2.5}(r=0.44, p<0.001)$ and $\mathrm{PM}_{1}(r=0.4, p<0.05)$ with airborne fungi concentration at $0.5 \mathrm{~m}$. However, there was no significant correlation with airborne fungal concentrations at $2 \mathrm{~m}$. In this study, high correlation coefficients were found between PM concentrations with airborne 
Table 2 Matrix of Spearman correlation between analyzed parameters in dental departments
**Correlation is significant at the 0.01 level (2-tailed)

*Correlation is significant at the 0.05 level (2-tailed)
(1)

(2)

(3)

(4)

(5)

(6)

(7)

(8) microorganisms at both distances $(0.5$ and $2 \mathrm{~m})$ (Table 2). However, the correlation coefficient of bacterial concentration at $2 \mathrm{~m}$ and PM concentration was higher than that at $0.5 \mathrm{~m}$. The predominant airborne bacterial genera in the five sampling sections were Micrococcus sp. (38.2\%), Bacillus sp. (22.2\%), Streptococcus sp. (19.8\%), and Staphylococcus sp.(19.8\%) of the total detected bacteria (Fig. 4a). The prevalent fungal genera isolated from the air samples were Penicillium (29\%), Cladosporium (26\%), Aspergillus (12\%), Rhizopus (11\%), and Alternaria (9\%) (Fig. 4b). The other detected fungi

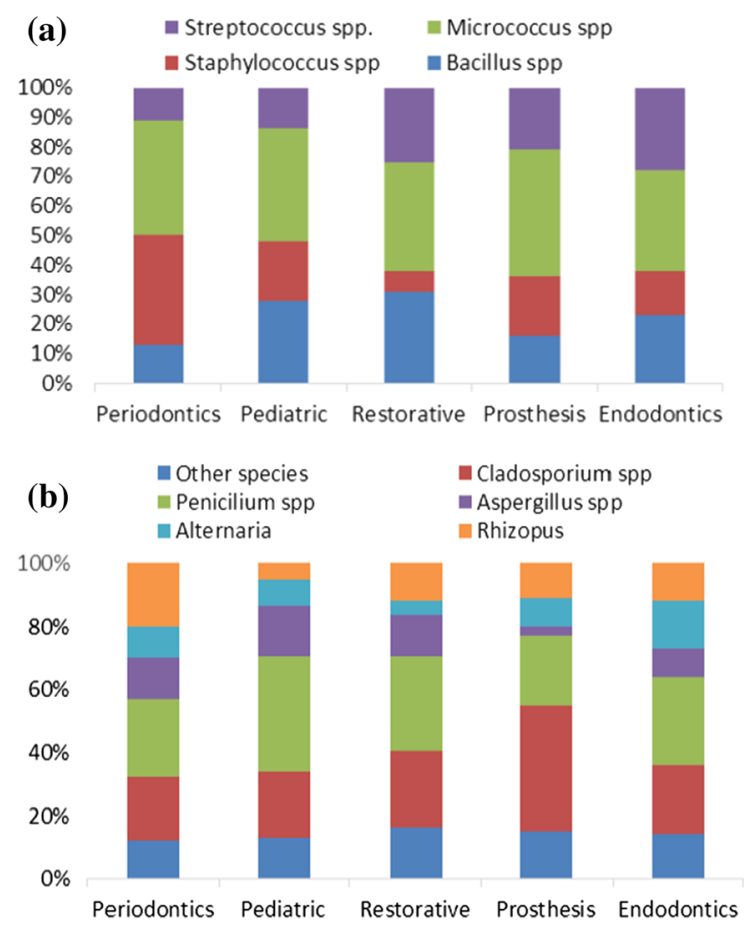

Fig.4 Contributions of $\mathbf{a}$ bacterial genera and $\mathbf{b}$ fungal spores genera at different dentistry departments
(14\%) included Mucor, Fusarium, Ulocladium, Paecilomyces and Mycelium.

\section{Discussion}

In order to prevent infectious diseases related to the indoor environment, the monitoring and control of microbial aerosols are of great importance in the dental school clinic. Bioaerosols contaminations in the dental clinic may have different indoor sources such as patients, treatment procedures, and dental staff or outdoor sources (Kimmerle et al. 2012). In part of the present study, the quantitative level of bacterial contamination in the educational dental clinic wards during the dental treatment procedure at two different distances $(0.5$ and $2 \mathrm{~m})$ from the dental chair was assessed. These findings show the changes of airborne bacteria concentrations during the various treatment process which is in accordance with data reported by some authors (Adhikari et al. 2017; Chuang et al. 2014). It should be noted that the comparisons of the CFU counts of various studies are very difficult to do and may not be defensible because the microbial aerosols in the dental clinic environment may be affected by various factors such as the type and position of air sampler, and environmental factors. However, standardization of the air sampling procedure by taking a similar sampler and the distance to the treatment dental chair can be helpful for such comparison. The results showed a significantly higher concentration level of airborne bacteria in pediatric wards than that in other sampling sites. This increase is probably due to the type of treatment procedure in this ward and higher mean number of occupants, active dentists and dental staff. Previous studies have reported that bioaerosol concentration and 
composition varies from patient to patient, depending on the department and type of procedure in the oral cavity (Choi et al. 2018; Kimmerle et al. 2012). Previous findings have also shown that the highest load of microbial aerosol and splatter dispersion happens during the use of an ultrasonic scaler tip and high-speed handpiece (Szymanska 2007).

The concentration levels of airborne bacteria in pediatric, endodontics, and restorative wards were significantly higher at 0.5 than those at $2 \mathrm{~m}$. In accordance with this study, Manarte-Monteiro et al. (2013) showed that the airborne bacterial load at a distance of $0.5 \mathrm{~m}$ was significantly higher than $2 \mathrm{~m}$ in the dentistry and endodontic practices in a university clinic. Contrary to these results, Rautemaa et al. (2006) reported that the density of airborne bacteria in restorative dentistry at distances $>1.5 \mathrm{~m}$ from the dental chair was higher than at distances $<1 \mathrm{~m}$. They believed that the high speed of instrument rotation causes a greater velocity and longer angular trajectory of bacteria. Chiramana et al. (2013) observed that the maximum spread of aerosols occurred at a $0.6 \mathrm{~m}$ distance from the patient in all angles, whereas aerosol scattering was negligible at a $1.8 \mathrm{~m}$ distance in all angles. In a study by Szymańska (2006), the airborne concentration of fungi ranged from 10 to $340 \mathrm{CFU} / \mathrm{m}^{3}$ during conservative dental treatment at individual operative sites. Also, it was found that the dental unit waterlines (DUWL) disinfection causes a decrease in the fungal aerosol concentrations. Therefore, waterlines of the dental units could be a source of airborne fungi. Naturally, the dentists are more susceptible to infection, since they work at a distance of $0-0.5 \mathrm{~m}$ from the oral cavity of a patient during most treatment actions. A study evaluated the risk of contamination of the dentists' face through the aerosol spread of the high-speed handpiece during dental treatment, reported that the eyes and around the nose were the most affected parts of the dentists' faces (Nejatidanesh et al. 2013). Our results indicated that the fungi levels at a distance of $0.5 \mathrm{~m}\left(103 \mathrm{CFU} / \mathrm{m}^{3}\right)$ were significantly higher than those at $2 \mathrm{~m}\left(63 \mathrm{CFU} / \mathrm{m}^{3}\right)$ from the patient in all of five sampling sites. Oliveira et al. (2018) suggested that the minimum safety distance between two dental chairs must be higher than $2 \mathrm{~m}$ and the glass wall is efficient barriers in controlling the scattering of airborne fungi in the dental wards.

In our study, the increased PM levels were observed in the periodontics ward, which can be due to the treatment procedure used in this ward of the dental clinic. Scaling by high-speed dental handpieces, tooth extraction, and oral surgeries are possible main sources of PM levels (Hong et al. 2015). On the other hand, the high numbers of patients, dental staff, and dental students may cause an increase in PM concentrations. Human density is a very effective factor in $\mathrm{PM}$ and microbial aerosol concentrations in the air of densely occupied wards, such as an educational environment in dental school. The $\mathrm{PM}_{10}$ and $\mathrm{PM}_{2.5}$ concentrations obtained in this study are comparable with the data reported by some studies (Helmis et al. 2008; Hong et al. 2015). Sotiriou et al. (2008) demonstrated that the drilling actions during surgery in the dental office are related with the particles smaller than $0.5 \mu \mathrm{m}$ and no significant levels of larger particles (larger than $1 \mu \mathrm{m}$ ) were correlated with these treatment actions.

The good correlations were obtained between bacteria and fungi and PM concentrations in the five wards. Other studies have also reported a correlation between PM concentration with indoor bioaerosols (Huang et al. 2018; Z. Liu et al. 2014). In contrast, Hospodsky et al. (2015) reported that there was no significant correlation between bacteria and fungi with particulate concentrations in indoor air. In our study, there was a positive good association between bacterial aerosol levels and $\mathrm{PM}$ concentrations $\left(\mathrm{PM}_{10}\right.$, $\mathrm{PM}_{2.5}$ and $\mathrm{PM}_{1}$ ). On the other hand, the microbial quality monitoring of indoor air by the culture methods are time-consuming and labor-intensive. Therefore, real time measurement of PM concentrations might enable an approximation of indoor air bacterial levels.

In the current survey, Gram-positive Cocci dominated in all isolates. Similar to past studies, Micrococcus sp. Bacillus sp, Streptococcus sp. and Staphylococcus $s p$. were the most bacteria isolated from the air of the dental office (Adhikari et al. 2017; Kimmerle et al. 2012; Manarte-Monteiro et al. 2013). Micrococcus and Staphylococcus have a human source. Streptococcus is the major cause of infection in immunocompromised patients and is the resident flora of the skin, human respiratory and gastrointestinal tract (Mirhoseini, et al. 2016).

In our study, Penicillium spp., Cladosporium spp., Aspergillus spp., Rhizopus, and Alternaria spp. isolates were the most prevalent fungi occurring in the environment of the dental clinic. All detected fungal 
species can be the main cause of the pathogenicity and the allergic rhinitis, asthma, and systemic acquired infection in the patient and the dental professionals. Unfortunately, few studies have been performed on the levels and composition of airborne fungi in the environment of dental clinics (Oliveira et al. 2018; Kadaifciler and Cotuk 2014; Szymańska 2006)). However, the fungal flora composition identified in these studies showed a similarity with our findings. For example, Kadaifciler and Cotuk (2014) in evaluating fungal aerosols of 20 dental offices found that Aspergillus spp., Penicillium spp., and Cladosporium spp. were the most common species and airborne fungi concentration was less than $100 \mathrm{CFU} / \mathrm{m}^{3}$. In another study, the most prevalent fungi in the air around 25 dental units during dental treatment were Penicillium herquei, Alternaria alternate, Penicillium roseopurpureum, Rhizopus nigricans, and Aspergillus terreus (Szymańska 2006). The fungi analysis of aerosols created by high-speed pen in two educational clinics in Brazil showed that Curvularia clavata Jain, Phialemonium obovatum, Aspergillus niger, Curvularia geniculate, Scopulariopsis koningii and Paecilomyces lilacinus were the most frequent fungal genera (Oliveira et al. 2018). The total airborne bacterial concentrations were higher than the fungal concentrations in all the indoor environments of dental clinic. A possible reason for this is attributed to the potential of the spread of these bacteria from human respiratory system and skin (Kobza et al. 2018). Additionally, due to the greater aerodynamic diameter, the fungal particles settle down faster than bacteria (M.-H. Liu et al. 2017).

\section{Conclusion}

This study confirmed the necessity of the management of potential infection risk among both dental staff and patients because of particle aerosols. Indoor microbial aerosols are caused by multiple origins such as patients, type of treatment procedure, and human occupancy and activity. The findings showed that the pediatric and periodontics wards had the highest $\mathrm{CFU}$ count of airborne bacteria and fungi, respectively. It was also found that the levels of bacterial aerosols in pediatric, endodontics, and restorative wards and fungal aerosols in five sampling wards at a distance $0.5 \mathrm{~m}$ were significantly higher than that at a distance
$2 \mathrm{~m}$ from the dental chair. Therefore, this study recommends that a minimum of 2-m distance from a dental chair is an appropriate action to decrease the risks of airborne infections. The air microbiological assessments are time-consuming and labor-intensive, thus we suggested that the potential dispersion of bacterial and fungal aerosols in the indoor air of dental offices can be estimated via monitoring of PM concentrations. In general, the activities related to dental treatment have a significant impact on the abundance of airborne opportunistic microorganisms.

Acknowledgement This research was funded by Arak University of Medical Sciences (Grant No. 3341). The authors wish to extend their thanks to dentists and staff of the Faculty of Dentistry, Arak University of Medical Sciences.

\section{References}

Adhikari, A., Kurella, S., Banerjee, P., \& Mitra, A. (2017). Aerosolized bacteria and microbial activity in dental clinics during cleaning procedures. Journal of Aerosol Science, 114, 209-218.

Chiramana, S., Bindu, O. S. H., Kadiyala, K. K., Prakash, M., Prasad, T. D., \& Chaitanya, S. K. (2013). Evaluation of minimum required safe distance between two consecutive dental chairs for optimal asepsis. Journal of Orofacial Research, 3(1), 12-15.

Choi, J.-O., Choi, Y.-J., \& Nam, S.-H. (2018). Study on the prevention of cross-infection by aerosols during scaling. Biomedical Research, 29(18), 3479-3482.

Chuang, C.-Y., Cheng, H.-C., Yang, S., Fang, W., Hung, P.-C., \& Chuang, S.-Y. (2014). Investigation of the spreading characteristics of bacterial aerosol contamination during dental scaling treatment. Journal of Dental Sciences, 9(3), 294-296.

Dawson, M., Soro, V., Dymock, D., Price, R., Griffiths, H., Dudding, T., et al. (2016). Microbiological assessment of aerosol generated during debond of fixed orthodontic appliances. American Journal of Orthodontics and Dentofacial Orthopedics, 150(5), 831-838.

Helmis, C. G., Tzoutzas, J., Flocas, H. A., Halios, C. H., Assimakopoulos, V. D., Stathopoulou, O. I., et al. (2008). Emissions of total volatile organic compounds and indoor environment assessment in dental clinics in Athens Greece. International dental journal, 58(5), 269-278.

Hong, Y.-J., Huang, Y.-C., Lee, I.-L., Chiang, C.-M., Lin, C., \& Jeng, H. A. (2015). Assessment of volatile organic compounds and particulate matter in a dental clinic and health risks to clinic personnel. Journal of Environmental Science and Health, Part A, 50(12), 1205-1214.

Hospodsky, D., Yamamoto, N., Nazaroff, W. W., Miller, D., Gorthala, S., \& Peccia, J. (2015). Characterizing airborne fungal and bacterial concentrations and emission rates in six occupied children's classrooms. Indoor Air, 25(6), 641-652. 
Huang, H.-L., Lee, M.-K., \& Shih, H.-W. (2018). Assessment of indoor bioaerosols in public spaces by real-time measured airborne particles. Aerosol and Air Quality Research, 17(9), 2276-2288.

Jimson, S., Kannan, I., Jimson, S., Parthiban, J., \& Jayalakshmi, M. (2015). Evaluation of airborne bacterial contamination during procedures in oral surgery clinic. Biomedical and Pharmacology Journal, 8, 669-675.

Kadaifciler, D. G., \& Cotuk, A. (2014). Microbial contamination of dental unit waterlines and effect on quality of indoor air. Environmental monitoring and assessment, 186(6), 3431-3444.

Kimmerle, H., Wiedmann-Al-Ahmad, M., Pelz, K., Wittmer, A., Hellwig, E., \& Al-Ahmad, A. (2012). Airborne microbes in different dental environments in comparison to a public area. Archives of oral biology, 57(6), 689-696.

Kobza, J., Pastuszka, J. S., \& Brạgoszewska, E. (2018). Do exposures to aerosols pose a risk to dental professionals? Occupational Medicine., 68(7), 454-458.

Liu, M.-H., Tung, T.-H., Chung, F.-F., Chuang, L.-C., \& Wan, G.-H. (2017). High total volatile organic compounds pollution in a hospital dental department. Environmental monitoring and assessment, 189(11), 571.

Liu, Z., Li, A., Hu, Z., \& Sun, H. (2014). Study on the potential relationships between indoor culturable fungi, particle load and children respiratory health in Xi' an, China. Building and Environment, 80, 105-114.

Madureira, J., Paciência, I., Rufo, J. C., Pereira, C., Teixeira, J. P., \& de Oliveira Fernandes, E. (2015). Assessment and determinants of airborne bacterial and fungal concentrations in different indoor environments: Homes, child daycare centres, primary schools and elderly care centres. Atmospheric Environment, 109, 139-146.

Manarte-Monteiro, P., Carvalho, A., Pina, C., Oliveira, H., \& Manso, M. C. (2013). Air quality assessment during dental practice: Aerosols bacterial counts in an universitary clinic. Revista Portuguesa de Estomatologia, Medicina Dentária e Cirurgia Maxilofacial, 54(1), 2-7.

Mirhoseini, S. H., Didehdar, M., Akbari, M., Moradzadeh, R., Jamshidi, R., \& Torabi, S. (2020). Indoor exposure to airborne bacteria and fungi in sensitive wards of an academic pediatric hospital. Aerobiologia, 36(2), 1-8.

Mirhoseini, S. H., Nikaeen, M., Shamsizadeh, Z., \& Khanahmad, H. (2016). Hospital air: A potential route for transmission of infections caused by $\beta$-lactam-resistant bacteria. American journal of infection control, 44(8), 898-904.

Nejatidanesh, F., Khosravi, Z., Goroohi, H., Badrian, H., \& Savabi, O. (2013). Risk of contamination of different areas of dentist's face during dental practices. International journal of preventive medicine, 4(5), 611.

Oliveira, A. M. A. V., de Alencar, R. M., Porto, J. C. S., Ramos, I. R. B. F., Noleto, I. S., Santos, T. C., \& Mobin, M. (2018). Analysis of fungi in aerosols dispersed by high speed pens in dental clinics from Teresina, Piaui. Brazil. Environmental monitoring and assessment, 190(2), 56.

Rautemaa, R., Nordberg, A., Wuolijoki-Saaristo, K., \& Meurman, J. H. (2006). Bacterial aerosols in dental practice-a potential hospital infection problem? Journal of hospital infection, 64(1), 76-81.

Sawhney, A., Venugopal, S., Babu, G. R., Garg, A., Mathew, M., Yadav, M., et al. (2015). Aerosols how dangerous they are in clinical practice. Journal of clinical and diagnostic research: JCDR, 9(4), ZC52.

Schmalz, G., Hickel, R., van Landuyt, K. L., \& Reichl, F.-X. (2018). Scientific update on nanoparticles in dentistry. International dental journal, 68(5), 299-305.

Sotiriou, M., Ferguson, S. F., Davey, M., Wolfson, J. M., Demokritou, P., Lawrence, J., et al. (2008). Measurement of particle concentrations in a dental office. Environmental monitoring and assessment, 137(1-3), 351.

Szymańska, J. (2006). Exposure to airborne fungi during conservative dental treatment. Annals of Agricultural and Environmental Medicine, 13(1), 177-179.

Szymanska, J. (2007). Dental bioaerosol as an occupational hazard in a dentist's workplace. Annals of Agricultural and Environmental Medicine, 14(2).

Timmerman, M. F., Menso, L., Steinfort, J., Van Winkelhoff, A. J., \& Van Der Weijden, G. A. (2004). Atmospheric contamination during ultrasonic scaling. Journal of clinical periodontology, 31(6), 458-462.

Zemouri, C., de Soet, H., Crielaard, W., \& Laheij, A. (2017). A scoping review on bio-aerosols in healthcare and the dental environment. PLoS ONE, 12(5), e0178007.

Publisher's Note Springer Nature remains neutral with regard to jurisdictional claims in published maps and institutional affiliations. 